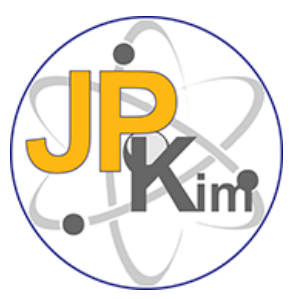

Jurnal Pendidikan Kimia

Vol. 13 | No. 1 |48 - 53| April | 2021

ISSN: 2085-3653| e-ISSN: 2549-3116

https://jurnal.unimed.ac.id/2012/index.php/jpk

https://jurnal.unimed.ac.id

\title{
Need analysis for the development of chemical literation integrated problem-solving module
}

\author{
Rodi Edi', Maefa Eka Haryani' and Eka Ad'hiya1,* \\ ${ }^{1}$ Department of Chemistry Education, Universitas Sriwijaya, Sumatera Selatan, Indonesia \\ *Corresponding author: EA, ekaadhiya@fkip.unsri.ac.id
}

DOI: $10.24114 /$ jpkim.v13i1.24143

Article history:

Received: 17 February 2021

Revised: 23 March 2021

Accepted: 24 March 2021

Abstract: This research is a descriptive survey research to analyze student needs for chemical literation integrated problem solving modules. The questionnaire was given to 89 active students of chemistry education at Sriwijaya University who were selected using a non-probability sampling technique. The results of the questionnaire were then analyzed using descriptive statistical tests. The results of this study indicate that students understand the qualifications needed as an undergraduate and are in the process of achieving this, and they agree to develop problem-solving integrated chemical literacy based basic chemistry modules as teaching materials that can help them to achieve the competences.

Keywords: Chemical literation, Problem-Solving, Module, Chemistry

\section{Introduction}

The development of science and the continuing competition in the world of work today, college graduates have a graduate profile according to their level and field of expertise (Nugrahadi et al. 2018). The industrial revolution 4.0 demands that many things change, especially in the field of education which is required to have graduates who are competent in the world of work (Namira et al. 2020; Rahman et al. 2020). In Indonesia there is a graduate qualification standard for each level of education called the Indonesian National Qualifications Framework. Indonesian National Qualifications Framework is a national reference to produce quality and productive national human resources (Faisal \& Lova, 2018).

Based on Presidential Regulation No.8 of 2012 concerning Indonesian National Qualifications Framework, it is explained that bachelor graduates must have a level 6 qualification, where one of the qualifications is "Able to apply their fields of expertise 
and utilize science, technology, and / or arts in their fields in solving problems and being able to adapt to the situation at hand".

Based on the qualification framework for undergraduate graduates, it is stated that they are able to apply knowledge for solving or solving problems. In'am (2014) explains that in the problem-solving process, students must understand the problem, then they must make a plan to solve the problem, and in solving this problem, bright ideas are needed to find effective and accurate solutions. Students who learn to use the problem solving stage influence their thinking process, where they apply and evaluate problems in a positive way (Ersoy, 2016). Polya's problem solving model starts with giving problems, which then students understand the problem and compile and execute problem-solving strategies to find conclusions, where these stages can improve students' skills in solving mathematical problems (Sholihah \& Efendi, 2017; Silaban, 2017).

The ability to adapt at the hand is one of the abilities that students must have. This is related to literacy skills. Understanding the scientific process is one of the scientific literacy abilities where someone with scientific literacy will be able to interpret scientific information available in everyday life (Fives et al. 2014). A person who has literacy skills can use scientific information to deal with problems in everyday life and also to produce several useful scientific products (Fitriani et al. 2018). Students must be trained to have the ability to apply the competencies of science they learn from school to become well-behaved people in society and conversely they can take advantage of society and the environment as learning resources to become wiser people in making decisions in their lives (Rokhmah et al. 2017).

Therefore, it is necessary to analyze the needs of students to achieve the framework of Indonesia's national qualifications for undergraduate level. Needs analysis is a very powerful tool to help clarify and validate students' real needs, wants and interests (Akyel \& Ozek, 2010). Needs analysis surveys have become part of the evaluation of learning programs to gather what is needed to improve the curriculum, accountability from policy makers and specifying content (Mehrdad, 2012).

One part of the student's needs in the learning process is teaching materials. Salam (2017) explains that in the learning process, students will be greatly helped by the existence of good teaching materials, which are in accordance with the needs of students and lecturers, so it is necessary to develop teaching materials if current conditions do not suit the needs. Teaching materials in the form of modules can facilitate students to learn, both with their teachers and independently (Arantika et al. 2018).

Thus, researchers feel the need to conduct a needs analysis for the development of teaching materials based Chemical literacy integrated problem-solving to encourage students to achieve the competence frameworks for Indonesian national qualifications. 


\section{Methods}

This research is a descriptive survey research. This study aims to analyze students' needs for developing integrated problem solving based literacy modules that can support achieving IQF by survey methods. Participants in the study were obtained using a non-probability sampling method, where at first the participants were selected using purposive sampling, namely active students of the FKIP UNSRI chemistry education study program, and continued with voluntary sampling techniques, namely voluntary taking of participants, so that the participants in this study consisted of 89 students are active in chemistry education department, Universitas Sriwijaya in the 2020/2021 academic year.

The instrument used in this study was a questionnaire. The questionnaire consisted of 6 questions developed from 3 aspects, namely Neccesity, Lack, and Need. Data were analyzed using SPSS Version 16.0 application, to analyze several statistical tests, namely descriptive statistics.

\section{Results and Discussion}

The aspect of neccesity is something that should be owned by students of the chemistry education department, Sriwijaya University. According to the Presidential Regulation of the Republic of Indonesia Number 8 of 2012 concerning the Indonesian National Qualifications Framework, undergraduate qualifications include qualification levels 6, namely for diploma 4 graduates, applied undergraduate and undergraduate.

The qualifications that should be (Neccesity) for undergraduate chemistry education are:

a. Able to apply their fields of expertise and take advantage of science, technology, and / or art in their fields in solving problems and being able to adapt to situations at hand.

b. Mastering the theoretical concepts of a particular field of knowledge in general and the theoretical concepts of a special section of the knowledge field in depth, and being able to formulate solutions to procedural problems.

c. Able to make correct decisions based on analysis of information and data, and able to provide guidance in choosing various alternative solutions independently and in groups.

d. Responsible for his own work and can be given responsibility for the achievement of the work of the organization.

Based on the results of the questionnaire distributed to students, it was found that $66.9 \%$ of students understood the qualifications they had to achieve at graduation as an undergraduate. Meanwhile, 33.1\% did not understand the qualifications. Although the percentage is smaller for those who do not understand Indonesian National Qualifications Framework, this should not be ignored, efforts need to be made to improve this situation, because Indonesian National 
Qualifications Framework is also the basis for the formulation of graduate learning outcomes which is then used as a reference in determining the level of depth and breadth of learning material (Permenristekdikti No.44 of 2015).

Most of the students ( $89 \%$ ) stated that they were in the process of achieving the Indonesian national qualifications for this undergraduate level. One aspect that can support students in the process of achieving Indonesian National Qualifications Framework is the need for teaching materials. This is in line with Viswanathan's (2013) explanation that the need to prepare effective learning material arises when students are faced with training to prepare student careers.

Students $(79,3 \%)$ answered that basic chemistry is an important subject that will be able to assist them in achieving the competency framework for Indonesian national qualifications as Chemistry Education students who are prospective high school chemistry teachers. General / basic chemistry in the higher education curriculum intends to shape future professionals with the necessary skills to analyze and solve problems in a sustainable manner (Figuieredo et al. 2016). In addition, Swoope (2020) explains that general / basic Chemistry is an important subject area that is relevant and thoughtful for a variety of significant disciplines, careers and areas of life.

$54.2 \%$ of students think that current teaching materials can help to achieve Indonesian National Qualifications Framework, while $46.6 \%$ of students think that current teaching materials cannot help to achieve KKNI. However, as many as $98.3 \%$ of students stated that they needed the development of teaching materials that could help you to be able to implement the standards frameworks in Indonesian National Qualifications. Thus the teacher's creativity is needed in making teaching materials that can attract students' attention, one of which is the module (Syafitri \& Darmana, 2018; Harefa et al. 2020). Harefa \& Silalahi (2020) in his research shows that there is an influence on motivation and learning outcomes by using modules.

Based on the results of the researcher's literature study, PISA (2013) explains that competence in explaining phenomena scientifically, designing scientific inquiry, interpreting data scientifically can be seen if someone has chemical literacy.

According to the method of Polya (1985) in solving problems, there can be four stages: understanding the problem, planning a strategy for problem solving, implementing the problem and reviewing the results obtained. In the problem solving model, students are guided to think critically and use their reasoning in solving problems (Maulina \& Sudarman, 2016).

Based on these literatures, the module based Chemical literacy integrated problem-solving is deemed necessary and approved by students to be developed. This is evident from the results of the questionnaire which showed that $98.3 \%$ of students agreed to develop a module based Chemical literacy integrated problemsolving. 


\section{Conclusion}

The result of this study show that students understand the qualifications needed as an undergraduate and are in the process of achieving this, and they agree to develop problem-solving integrated chemical literacy based basic chemistry modules as teaching materials that can help them to achieve the competences.

\section{Acknowledgment}

This research was funded by the Public Service Agency DIPA Budget Sriwijaya University 2020 Fiscal Year No.SP DIPA-023.17.2.677515 / 2020, Revision to 01 dated March 16, 2020. In accordance with the Chancellor's Decree Number: 0684 / UN9 / SK.BUK.KP / 2020.

\section{References}

Akyel, A.S., \& Ozek, Y. (2010). A language needs analysis research at an English medium university in Turkey. Science Direct-Procedia Social and Behavioral Sciences, 2, 969-975, DOI: 10.1016/j.sbspro.2010.03.136

Arantika, J., Saputro, S., \& Mulyani, S. (2018). Student's need analysis for the development of chemistry modules based guided inquiry to improve science process skill. International Journal of Pedagogy and Teacher Education (IJPTE), 2, 53-60, DOI: 10.20961/ijpte.v2io.19750

Ersoy, E. (2016). Problem solving and its teaching in mathematics. The Online Journal of New Horizons in Education, 6(2), 79-87.

Faisal, \& Lova, S.M. (2018). Persepsi Mahasiswa PGSD terhadap Implementasi KKNI di Universitas Negeri Medan. Jurnal Inovasi Pendidikan Dan Pembelajaran Sekolah Dasar, 2(1), 37-47, DOI: 10.24036/jippsd.v2i1.100047

Figueiredo, M., Neves, J., Gomes, G., \& Vicente, H. (2016). Assessing the role of general chemistry learning in higher education. Procedia - Social and Behavioral Sciences, 228, 161 168, DOI: 10.1016/j.sbspro.2016.07.024

Fitriani, Harahap, F., \& Manurung, B. (2018). Biology scientific literacy of indonesian students: Case study in Aceh Tamiang - Aceh. International Journal of Research \& Review, 5(3), 6372.

Fives, H., Huebner, W., Birnbaum, A.S., \& Nicolich, M. (2014). Developing a measure of scientific literacy for middle school students. Science Education, 98(4), 549-580, DOI: $10.1002 /$ sce. 21115

Harefa, N., \& Silalahi, N.F.D. (2020). Improvement of student's learning outcomes and motivation with chemical practicum e-module. Jurnal Pendidikan Kimia, 12(1), 10-14. DOI: 10.24114/jpkim.v12i1.17708

Harefa, N., Sinaga, M., \& Silaban, S. (2020). Students perception and interest on chemistry: Learning evaluation integrated quizziz media. Jurnal Pendidikan Kimia, 12(3), 143-150. DOI: 10.24114/jpkim.v12i3.21163

In'am, A. (2014). The implementation of the polya method in solving euclidean geometry problems. International Education Studies, 7(7), 149-158, DOI: 10.5539/ies.v7n7p149 
Maulina, J., \& Sudarman, S. (2016). Learning research methods of based problem solving reviewed from cognitive and critical thinking ability. Jurnal Pendidikan Kimia, 8(1), 1-4.

Mehrdad, A.G. (2012). A subjective needs assessment of EGP students. Sciverse science directProcedia social and behavioral sciences, 31, 546-554, DOI: 10.1016/j.sbspro.2011.12.101

Namira, F., Azura, W., Miranda, A., Nisa, H., Silaban, S., Suyanti, S., \& Darmana, A. (2020). Analysis of constraints and innovation of chemistry experiment implementation in high school in Deli Serdang, Indonesia. Jurnal Pendidikan Kimia, 12(3), 106-115, DOI: 10.24114/jpkim.v12i3.21159

Nugrahadi, E.W., Maipita, I., \& Putra, P.D. (2018). Analisis implementasi kurikulum berbasis KKNI di Fakultas Ekonomi UNIMED. Niagawan, 7(1), 8-13.

Peraturan Presiden Nomor 8 Tahun 2012 tentang Kerangka Kualifikasi Nasional Indonesia (KKNI) pada 17 Januari 2012.

Rahman, G., Nasution, R. F., Lubis, A. R., Novira, P., Rahman, L., Sinaga, E. H. R., ... \& Silaban, S. (2020). Analysis of constraints and alternative solutions to the implementation of chemical practicums in several high schools in Medan. Jurnal Pendidikan Kimia, 12(1), 4451. DOI: $10.24114 /$ jpkim.v12i1.17744

Rokhmah, A., Sunarno, W., \& Masykuri, M. (2017). Science literacy indicators in optical Instruments of highschool physics textbooks Chapter. Jurnal Pendidikan Fisika Indonesia, 13(1), 19-24, DOI: 10.15294/jpfi.v13i1.8391

Salam, S. (2017). Developing needs analysis based-reading comprehension learning materials: A study on the indonesian language study program students. Advances in Language and Literary Studies, 8(4), 105-113, DOI: 10.7575/aiac.alls.v.8n.4p.105

Sholihah, A.U., DJ, L., Efendi, J. (2017). Development of stoichiometry module based on problem solving for grade $X$ of high school students. International Journal of Research in Counseling and Education, 1(1), 1-9, DOI: 10.24036/005za0002

Silaban, S. (2017). Dasar-dasar pendidikan matematika dan ilmu pengetahuan alam. Medan: Harapan Cerdas Publisher.

Swoope, M.W. (2020). What impacts the student outcome in general chemistry?. Modern Chemistry \& Applications, 8(1), 1-3.

Syafitri, A., \& Darmana, A. (2018). Development of chemistry module integrated with islamic values in thermochemistry and reaction rate for senior high school student. Jurnal Pendidikan Kimia, 10(3), 418-423, DOI: 10.24114/jpkim.v10i3.12720

Viswanathan, R. (2013). Designing learning materials for students- A gateway to teacher development. Journal of Technology for ELT, 3(1), 1-7. 